\title{
PENYELESAIAN SENGKETA TANAH PEKARANGAN DESA DI DESA ADAT SULAHAN KECAMATAN SUSUT KABUPATEN BANGLI
}

\author{
I Putu Ade Surya, I Made Suwitra, I Ketut Sukadana \\ Fakultas Hukum Universitas Warmadewa, Denpasar-Bali, Indonesia
}

\begin{abstract}
Abstrak
Tanah dalam kehidupan manusia mempunyai peran yang sangat penting karena merupakan sumber kesejahteraan, kemakmuran, dan kehidupan. Selain itu tanah mempunyai hubungan yang erat dalam manusia karena tanah mempunyai nilai ekonomis bagi kehidupan manusia dan dapat menghasilkan sumber daya alam bagi orang banyak. Hak atas tanah dalam hukum adat ada 2 (dua) yaitu hak atas tanah yang dikuasai oleh perorangan dan hak atas tanah yang dikuasai oleh masyarakat hukum adat atau tanah ulayat. Bedasarkan hal tersebut dapat diambil rumusan masalah sebagai berikut: (1) Bagaimanakah eksistensi tanah pekarangan desa dalam awig-awig Desa Adat Sulahan Kecamatan Susut Kabupaten Bangli? (2) Bagaimanakah penyelesaian kasus sengketa tanah pekarangan desa di Desa Adat Sulahan Kecamatan Susut Kabupaten Bangli?. Metode penelitian yang digunakan adalah penelitian hukum empiris, yaitu penelitian hukum yang berfungsi untuk melihat hukum dalam artian nyata dan meneliti bagaimana bekerjanya hukum di lingkungan masyarakat. Pendekatan masalah yang digunakan berupa pendekatan Sosiologi hukum yaitu suatu penelitian hukum yang mengkaji fakta-fakta hukum yang ada di masyarakat. Hasil penelitian menunjukan Penyelesaian sengketa tanah pekarangan desa di Desa Adat Sulahan biasanya diselesaikan dengan kekeluargaan dengan Bendesa Adat berperan sebagai mediatornya. Mediasi yang dilakukan oleh Prajuru Desa Adat Sulahan dalam menyelesaikan sengketa tanah pekarangan desa yang terjadi di Desa Adat Sulahan dilakukan di Pura Desa Sulahan. Tujuan pelaksanaan mediasi tersebut dilakukan di Pura Desa Sulahan dikarenakan ada letaknya yang strategis. Sebelum melakukan mediasi pihak Prajuru Desa Adat dan para pihak yang bersengketa akan mengadakan persembahyangan terlebih dahulu agar pelaksanaan mediasi dapat berjalan lancar sehingga tidak ada sengketa.
\end{abstract}

Kata Kunci: Desa adat sulahan; Sengketa tanah pekarangan desa; Tanah adat

\begin{abstract}
Land in human life has a very important role because it is a source of welfare, prosperity and life. In addition, land has a close relationship with humans because land has economic value for human life and can produce natural resources for many people. There are 2 (two) rights to land in customary law, namely the right to land controlled by individuals and the right to land controlled by customary law communities or customary land. Based on this, the formulation of the problem can be taken as follows: (1) How is the existence of the village yard land in the awig-awig of Sulahan Traditional Village, Susut District, Bangli Regency? (2) How is the settlement of a village yard land dispute case in the Sulahan Traditional Village, Susut District, Bangli Regency? The research method used is empirical legal research, namely legal research which functions to see the law in a real sense and to examine how the law works in society. The approach to the problem used is in the form of a sociology of law approach, which is a legal research that examines legal facts that exist in society. The results showed that the settlement of village yard land disputes in the Sulahan Traditional Village was usually resolved by kinship with Bendesa Adat acting as the mediator. Mediation carried out by Prajuru of Sulahan Traditional Village in resolving village yard land disputes that occurred in Sulahan Traditional Village was carried out at Pura Desa Sulahan. The purpose of the mediation was carried out at the Sulahan Village Temple because of its strategic location. Before conducting mediation, the Prajuru Desa Adat and the disputing parties will hold a prayer first so that the mediation can run smoothly so that there are no disputes.
\end{abstract}

Keywords: Sulahan traditional village; Land dispute village; Customary land

\section{PENDAHULUAN}

Masalah pertanahan di Indonesia telah muncul dalam banyak aspek dengan beragam wujud. Berbagai upaya penyelesaian telah ditawarkan baik melalui musyawarah atau mediasi tradisional maupun 
mediasi pertanahan yang dibentuk dalam lingkungan instansi Badan Pertanahan Nasional. Berbagai sengketa atau konflik merupakan salah satu bentuk konflik yang membutuhkan perhatian yang serius dari berbagai kalangan. Suatu permasalahan dapat mengakibatkan suatu gangguan menuju ketertiban umum, maka dari itu tanah sudah dianggap sebagai sebuah harta yang memang penting sekali sehingga, problem tentang tanah yang timbul menjadi lama dan terus-terusan. Tanah juga seringkali menghibahkan getaran dan sering menimbulkan kegoncangan dalam masyarakat, lalu sektor tanah mengakibatkan permasalahan dalam pembangunan nasional (Salindeho, 1998).

Dewasa ini seiring dengan perkembangan jaman khususnya di Bali makna dari palemahan yang terdapat pada filosofi Tri Hita Karana telah ternodai dengan banyaknya masyarakat yang serakah sehingga berdampak pada banyaknya kerusakan yang terjadi di alam sekitar. Jika dilihat disektor tanah banyak orang ingin mendapatkan hak atas tanah walau dengan cara apapun. Mulai dari yang membuat sertifikat ganda, mensertifikatkan tanah yang bukan menjadi hak miliknya sampai ada yang mengakui sebuah tanah memang kepunyaan Desa Adat. Terlebih dalam kehidupan sosial masyarakat desa ini yang penuh kekeluargaan tidak menutup juga sebuah masalah yang berkaitan dengan kepentingan mereka semua di lungkungan sektor perdata seperti sengketa tanah pekarangan desa, yang menimbulkan sengketa dalam lingkungan keluarga mereka sendiri. Seperti salah satu permasalahan yang terjadi di Desa Sulahan Kecamatan Susut Kabupaten Bangli, yang dimana di desa ini telah terjadi sengketa tanah pekarangan desa yang melibatkan keluarga I Dewa Made Ugi sebagai penggugat dengan keluarga I Dewa Nyoman Lungi sebagai tergugat

Penelitian terdahulu telah dikaji oleh (Apriyani, 2018) menyimpulkan bahwa kurangnya pengetahuan masyarakat mengenai hukum adat untuk mentaati norma hukum, kemudian kurangnya dukungan masyarakat dalam pelaksanaan norma hukum dan kesengajaan dalam mengabaikan norma hukum. Berikutnya mensertifikatkan tanah adat tersebut dengan menjadikan desa pakraman sebagai subyek hukumnya, mengingat tentang Penunjukan Desa Pakraman Di Provinsi Bali Sebagai Subyek Hukum Pemilikan Bersama (Komunal) Atas Tanah berdasarkan Keputusan Menteri Agraria Dan Tata Ruang Badan Pertanahan Nasional Nomor 276/KEP-19.2/X/2017. Adapun tujuan penelitian ini yaitu mengetahui eksistensi tanah pekarangan desa dalam awig-awig dan mengetahui penyelesaian kasus sengketa tanah pekarangan desa di Desa Adat Sulahan Kecamatan Susut Kabupaten Bangli.

\section{METODE PENELITIAN}

Metode penelitian yang digunakan adalah penelitian hukum empiris, yaitu suatu metode penelitian hukum yang berfungsi untuk melihat hukum dalam artian nyata dan meneliti bagaimana bekerjanya hukum di lingkungan masyarakat. Pendekatan masalah yang digunakan berupa pendekatan Sosiologi hukum yaitu suatu penelitian hukum yang mengkaji fakta-fakta hukum yang ada di masyarakat. Sosiologi hukum didefinisikan sebagai suatu cabang ilmu pengetahuan yang secara empiris menganalisis atau mempelajari hubungan timbal balik antara hukum dengan gejala-gejala sosial yang ada di masyarakat (Soekanto, 1989). Sumber data yang dijadikan pedoman dalam penelitian ini adalah data primer dan data sekunder. Data Primer yaitu data yang diperoleh langsung dari sumbernya baik dari informan atau responden. Data Sekunder yaitu data yang diperoleh dari sumber kedua berupa bahan hukum, yaitu: Bahan Hukum Primer seperti: Undang-Undang Dasar Negara Republik Indonesia Tahun 1945, Undang-Undang Hukum Perdata.Perda Provinsi Bali No.4 Tahun 2019, Awig-awig Desa Adat Sulahan. Bahan Hukum Sekunder seperti: buku teks dan jurnal hukum. Pengumpulan data yang diperlukan sangat beragam untuk mendapatkan data yang akurat, jelas dan terpercaya. Agar hasil yang dicapai dapat memuaskan serta sebagai bukti keberhasilan dalam mendapatkan data yang diperlukan didalam penelitian yang dilakukan. Dalam pengumpulan data yang diperlukan menggunakan instrumen data sebagai berikut Pengumpulan Data Premier Metode Wawancara adalah suatu daftar yang berisikan berbagai pertanyaan, disusun secara tertulis mengenai suatu hal yang diajukan secara sistematis. Dengan ini penulis mendapatkan data dari para responden tentang variabel yang berkaitan dengan masalah yang akan penulis bahas, bentuk wawancara dibuat secara terstruktur dimana telah disiapkan pertanyaan-pertanyaan sebagai acuan dalam wawancara. Studi dokumen yaitu data dicari dalam dokumen atau sumber pustaka. Studi dokumen dilakukan dengan cara membaca, mempelajari dan mencatat beberapa dokumen yang berada pada situs internet, buku, dan data-data lainnya yang berhubungan dengan penelitian. Penelitian ini diadakan di Desa Adat Sulahan Kecamatan Susut Kabupaten Bangli, karena di Desa 
tersebut ditemukan adanya kasus sengketa penguasaan tanah Pekarangan Desa (PKD) yang peyelesaiannya dilakukan melalui Pengadilan (Litigasi). Analisis data dalam penelitian ini dilakukan secara kualitatif yaitu penelitian yang lebih memfokuskan sesuai dengan fakta yang terjadi di lapangan, kemudian dituangkan secara deskriptif.

\section{HASIL DAN PEMBAHASAN}

\section{Eksistensi Tanah Pekarangan Desa di Desa Adat Sulahan Kecamatan Susut Kabupaten} Bangli

Setiap masyarakat hidup dalam lingkungan alam yang juga berfungsi sebagai sumber daya agrarianya akan terjadi, jika masyrakat tersebut merupakan persekutuan hukum. Dengan demikian, masyarakat tidak sekedar dipahami sebagai kumpulan atau kelompok orang-orang saja yang berada dalam suatu wilayah tertentu. Hubungan antara persekutuan hukum dengan sumber daya agrarianya disebut dengan hak ulayat (Eman, 2006). Pengaturan pertanahan di Bali pasti berkaitan dengan hukum adat yang berada di Bali, terlepas dari aturan manapun, aturan di hukum adat memang lebih terstruktur karena aturan tersebut sudah ada sejak dahulu dikenal dengan istilah tanah adat, atau tanah druwen desa (tanah milik desa). Tanah ini bisa kita kaitkan dengan struktur kepustakaan hukum adat Bali yang di sebut "hak ulayat".

Perlu di ketahui juga bahwa tanah di Bali ini mempunyai jenis dan fungsi yang berbeda, diantaranya sebagai berikut:

1. Tanah Desa, merupakan tanah yang di jaga oleh masyarakat desa yang nantinya dapat digunakan usaha untuk pembelian maupun usaha apapun.

2. Tanah Laba Pura, ialah tanah yang dulu milik desa namun didirikan sebuah kawasan tempat suci yang di gunakan untuk keperluan kegiatan keupacaraan Pura tersebut.

3. Tanah Pekarangan Desa (PKD), adalah tanah yang di pegang atau di kuasai sepenuhnya oleh desa kepada krama desa yang didirikan untuk perumahan yang umumnya dalam tapak atau batasan tertentu yang hampir sama dalam setiap keluarga

4. Tanah Ayahan Desa (AYDS), adalah tanah yang dimana dikuasi oleh masyarakat desa yang pengerjaannya diberikan atau di persembahkan kepada para krama desa dinikmati hasilnya dan mendapatkan haknya (Suasthawa Dharmayuda, 2001).

Sebagaian tanah adat adalah berpilah menjadi hak kepunyaan bersamaan dari suatu sekumpulan masyarakat hukum adat dilihat sebagai tanah bersama yang diistilahkan "pemberian atau anugerah" oleh sebuah kekuatan gaib, dan oleh sebab itu apabila hak perorangan bersumber dari tanah yang bersama. Di sebutkan bahwa tanah ada tersebut seperti Pekarangan Desa (PKD), AYDS, dikuasai oleh individu yang dalamnya terkandung konsep Tri Hita Karana, yang berupa Mrajan (sebuah kepercayaan/belive system) yang di ambil dari konsep Parhyangan, kemudian Palemahan yang diartikan sebagai wujud wilayah rumah tersebut (artefact system), dan yang terakhir adalah konteks Pawongan yang kita tau "wong" itu artinya manusia, jadi berwujud sebagai keluarga tersebut (social system), yang merupakan konteks dari pada krama banjar adat tersebut dan sudah diatur oleh awigawig (Suwitra, 2009).

Perlunya sebuah hubungan kuat antara desa adat dengan tanah itu, dan setelah itu dibuatkan aturan yang kemudian disuratkan dalam awig-awig yang melarangkan adan pembagian hak atau beli jual kepada seseorang yang bukan merupakan krama desa tersebut, dan seperti yang tercantum dalam awig-awig memperoleh semua persetujuan melalui paruman desa atau di rapatkan. Oleh sebab itu maka ada pengaturan yang mengatur tentang tanah pekarangan desa dalam sebuat awig-awig desa adat. Dalam awig-awig di Desa Adat Sulahan di atur juga awig-awig yang mengatur tentang tanah pekarangan yaitu: Sargah III Sukerta Tata Krama, Palet V Indik Druwen Desa.

Pawos 28 awig-awig di Desa Adat Sulahan ditentukan:

1. Kawigunan tanah desa, pelaba pura wenang kaanggen ngupaayu kahyangan miwah anggen prabea, aci ring kahyangan manutdudonan.

2. Prajuru desa utawi banjar wenang ngetangan padruwean saha kakesiaran nyabran paruman antuk ilikita pastika.

Yang arti bebasnya adalah:

1. Kegunaan tanah desa, dipergunakan untuk membiayakan kegiatan upacara keagamaan di pura. 
2. Pengurus desa atau banjar adat mencatat kekayaan atau milik desa dan disiarkan setiap rapat dengan cacatan pasti.

Palet 6 SUKERTA MAPITEGEP Pawos 29

1. Karang desa sane kagenahin paumahang soang-soang manut dresta wantah paweweh desa maka cihna wala ayahan ring desa.

2. Sehanan karang patut:

1) Tan Kawenangan nyertipikatang

2) Pastika wenten waled ipun

3) Mapemedal karurung tan wenangkabengbeng. Kelian Desa, banjar patut ngutsahayang mangda sami karange kadi kawentenania.

Yang arti bebasnya:

1. Tanah desa yang di tempati untuk perumahan sesuai kebiasaan adalah hadiah untuk warga yang telah melakukan kewajiban terhadap desa

2. Setiap tanah wajib:

1) Tidak boleh disertifikatkan

2) Pasti ada yang menempati

3) Akses keluar rumag tidak boleh ditutup

\section{Penyelesaian Kasus Sengketa Tanah Pekarangan Desa di Desa Adat Sulahan Kecamatan Susut Kabupaten Bangli}

Dalam dunia hukum berbagai macam masalah pasti ada cara penyelesaiannya. Berbicara mengenai penyelesaian sengketa ada bebebrapa macam, salah satunya adalan Alternatif Penyelesaian Sengketa adalah Mediasi. Mengapa mediasi? Karena mediasi itu ialah salah satu cara menyelesaian sengketa yang berada diluar ranag peradilan (non-litigasi) dengan cara di bantu oleh seorang mediator atau orang yang mempunyai keahlian di bidangnya dan bersikap netral atau tidak memihak siapapun, dan juga melalui jalur ini jauh lebih murah dari pada jalur pengadilan (litigasi).

Konflik terjadi karena masing-masing pihak bersaing untuk mencapai tujuannya masingmasing dalam persaingan itu tentunya akan ada upaya untuk mengalahkan pihak lain dan dengan demikian salah satu pihak meraih kemenangan. Di dalam persaingan ini mungkin pula muncul persaingan yang tidak sehat yang menimbulkan kerugian pada pihak lain yang akhirnya melahirkan sengketa (Sembiring, 2011).

Selesai tidaknya sengketa yang terjadi akan sangat tergantung kepada model atau pola penyelesaian sengketa yang digunakan dan didukung oleh kemampuan dari personal yang terlibat dalam penyelesaian sengketa tersebut. Bendesa Adat Sulahan mengharapkan krama desanya atau warganya dalam penyelesaian sengketa dapat diselesaikan melalui musyawarah dengan berpedoman pada awig-awig yang ada. Awig-awig berasal dari kata "wid' yang artinya rusak, sedangkan "awig" artinya tidak rusak atau baik. Jadi awig-awig dimaknai sebagai sesuatu yang menjadi baik. Secara harfiah awig- awig memiliki arti suatu ketentuan yang mengatur tata krama pergaulan hidup dalam masyarakat untuk mewujudkan tata kehidupan yang ajeg di masyarakat (Surpha, 2012). Begitupula dengan Desa Adat Sulahan yang merupakan sebuah lembaga adat juga mempunyai hal serupa. Desa Adat Sulahan memiliki sebuah aturan adat yang digunakan sebagai aturan khusus untuk mengatur kehidupan masyarakat adatdalam wilayah kehidupan Desa Adat di luar kehidupan Desa Dinas yang berpedoman pada hukum nasional.

Penyelesaian sengketa tanah pekarangan desa di Desa Adat Sulahan biasanya diselesaikan dengan kekeluargaan dengan Bendesa Adat berperan sebagai mediatornya. Mediasi yang dilakukan oleh Prajuru Desa Adat Sulahan dalam menyelesaikan sengketa tanah pekarangan desa yang terjadi di Desa Adat Sulahan dilakukan di Pura Desa Sulahan. Tujuan pelaksanaan mediasi tersebut dilakukan di Pura Desa Sulahan dikarenakan karena letaknya yang strategis. Sebelum melakukan mediasi pihak Prajuru Desa Adat dan para pihak yang bersengketa akan mengadakan persembahyangan terlebih dahulu agar pelaksanaan mediasi dapat berjalan lancar (wawancara dengan Bapak I Ketut Dugdug selaku Bendesa Desa Adat Sulahan pada tanggal 12 Juni 2020 pukul 11.00 Wita).

Adapun proses pelaksanaan mediasi yang diakukan oleh Bendesa Desa Adat Sulahan dapat diketahui ada beberapa tahapan dalam pelaksanaan mediasi menyelesaikan sengketa tanah pekarangan desa yang terjadi di Desa Adat Sulahan yaitu: 
1. Pelaksanaan mediasi dilakukan oleh Bendesa Desa Adat Sulahan apabila adanya laporan dari pihak yang merasa dirugikan.

2. Setelah adanya laporan masuk dari pihak yang merasa dirugikan, kemudian laporan tersebut diperiksa oleh pihak Bendesa Desa Adat Sulahan untuk mengetahui apakah benar terjadi sengketa sesuai dengan apa yang telah dilaporkan.

3. Laporan yang diajukan oleh pihak yang merasa dirugikan tidak hanya berupa laporan secara lisan saja, tetapi harus dilengkapi oleh surat yang dibuat oleh pihak pelapor yang ditujukan kepada Kelian Desa Adat Sulahan.

4. Setelah itu Desa Adat Sulahan membentuk tim (Kerta Desa) untuk memeriksa dan mengevaluasi laporan yang telah masuk.

5. Kemudian tim yang telah dibentuk oleh Bendesa Desa Adat Sulahan ini (Kerta Desa) melakukan perencanaan untuk menyelesaikan masalah itu (nepasin wicara) berdasarkan awigawig yang berlaku di Desa Adat Sulahan.

6. Dibuatkan surat pemanggilan untuk kedua belah pihak yang bersengketa beserta saksi-saksi yang akan memberikan keterangan dan surat-surat seperti sertifikat untuk dijadikan bukti kepemilikan tanah.

7. Kemudian dilakukan Paruman (mediasi) yang dilakukan oleh Kerta Desa yang dihadiri oleh Prajuru Desa Adat Sulahan, Kerta Desa, saksi-saksi dan kedua belah pihak yang bersengketa.

8. Setelah dilakukannya Paruman (mediasi) maka selanjutnya para Kerta Desa akan memberikan keputusan atas permasalahan yang terjadi. Dasar-dasar pertimbangan bagi Kerta Desa dalam memberikan keputusan yaitu awig-awig yang berlaku di Desa Adat Sulahan. Bila masih ada waktu maka pada hari itu juga akan diputuskan, tetapi apabila karena tidak cukup waktu maka data-data yang ada akan dikaji dahulu oleh Kerta Desa kemudian akan dicarikan waktu untuk mengadakan Paruman (mediasi) kembali.

9. Kemudian kerta Desa memberikan keputusan atas permasalahan yang terjadi. Apabila keputusan yang dikeluarkan oleh Kerta Desa tersebut tidak diterima oleh kedua belah pihak yang bersengketa, maka akan dilakukan Paruman (mediasi) ulang untuk memberikan putusan yang baru.

10. Setelah diberikan keputusan yang baru oleh Kerta Desa, apabila masih tidak diterima oleh para pihak yang bersengketa maka, pihak Prajuru Desa Adat Sulahan akan menyerahkan kembali kepada para pihak yang bersengketa dan akan diselesaikan berdasarkan hukum positif.

Pada bagian akhir isi putusan yang dikeluarkan oleh Bendesa Desa Pakraman Buduk tersebut berisi ketentuan: "Bilamana bagi para pihak yang bersengketa tidak puas akan Putusan Desa Pakraman ini dapat dilanjutkan melalui pengadilan dan dalam pelaksanaan mediasi dihadiri oleh perbekel sebagai saksi dari unsur pemerintah (kedinasan)".Inti dari permasalahan sengketa tersebut di sebutkan bahwa pengadilan tidak mempunyai kewenangan dalam penyelesaian sengketa tanah adat atau pekarangan adat atau sejenisnya. Karena ini merupakan permasalahan adat maka harus mengikuti bagaimana aturan yang di atur dalam awig-awig di Desa Adat Sulahan tersebut dan diselesaikan secara adat juga.

\section{SIMPULAN DAN SARAN}

\section{Simpulan}

Berdasarkan uraian pada bab-bab tersebut diatas dapatlah ditarik kesimpulan sebagai berikut: Tanah adat merupakan hal terpenting di dalam penyedian pekarangan di desa adat manapun, Pengaturan tentang tanah pekarangan desa (PKD) memang berkaitan erat dengan adanya tanah adat di desa adat di Bali. Di Bali hal penguasaan tanah juga dilandasi oleh hak ulayat atau hak prabumian. Kondisi ini akan sangat relevan jika dikaitkan antara hubungan terjadinya desa adat dan tanah adat dalam perspektif sejarahnya. Hubungan antara hak komunal dengan hak individual juga nampak saling mendesak, menebal, dan menipis, bahkan lebih didominasikan oleh hak individual, terutama dalam pemanfaatan tanah pekarangan beserta telajakannya. Penyelesaian sengketa tanah pekarangan desa di Desa Adat Sulahan biasanya diselesaikan dengan kekeluargaan dengan Bendesa Adat berperan sebagai mediatornya. Mediasi yang dilakukan oleh Prajuru Desa Adat Sulahan dalam menyelesaikan sengketa tanah pekarangan desa yang terjadi di Desa Adat Sulahan dilakukan di Pura Desa Sulahan. Tujuan pelaksanaan mediasi tersebut dilakukan di Pura Desa Sulahan dikarenakan karena letaknya yang strategis. Sebelum melakukan mediasi pihak Prajuru Desa Adat dan para pihak yang bersengketa akan mengadakan persembahyangan terlebih dahulu agar pelaksanaan mediasi dapat berjalan lancar. 


\section{Saran}

Bertitik tolak dari kesimpulan yang telah dikemukakan diatas dapat disarankan hal sebagai berikut: Kepada pihak adat sebaiknya desa adat lebih menertibkan prihal tanah yang ditempatinya agar tidak menjadi permasalahan di kemudian hari. Kepada pihak yang bersengketa berhubungan dengan adat sebaiknya penyelesaiannya dilakukan secara adat lebih dahulu mengingat sengketa mekanisme penyelesaiannya secara adat.

\section{DAFTAR PUSTAKA}

Apriyani, P. I. (2018). Status Kepemilikan Tanah Adat di Bali yang diakui Sebagai Tanah Milik Pribadi. Acta Comitas, 3(2), 326.

Eman. (2006). Prinsip Hukum Ruang Bawah Tanah untuk Bangunan Gedung dalam Sistem Hukum Agraria Nasional. In Disertasi.

Salindeho, J. (1998). Masalah Tanah dalam Pembangunan. Sinar Grafika.

Sembiring, J. J. (2011). Cara Menyelesaikan Sengketa Diluar Pengadilan (Negosiasi, Mediasi, Konsiliasi, \& Arbitrase). Visimedia.

Soekanto, S. (1989). Mengenal Sosisologi Hukum. Citra Aditya Bakti.

Suasthawa Dharmayuda, I. M. (2001). Desa Adat, Kesatuan Masyarakat Hukum Adat Bali di Propinsi Bali. Upada Sastra.

Surpha, I. W. (2012). Seputar Desa Pakraman dan Adat Bali. Pustaka Bali Post.

Suwitra, I. M. (2009). Eksistensi Hak Penguasaan Dan Pemilikan Atas Tanah Adat Di Bali Dalam Perspektif Hukum Agraria Nasional. Disertasi, Program Doktor Ilmu Hukum Fakultas Hukum Universitas Brawijaya Malang. 